\title{
Variasi Temperatur Dan Waktu Destilasi terhadap Sifat Fisik, Kimia, dan Rendemen Air Laut Menggunakan Pemanas Elektrik
}

\author{
Muhammad Rusdi ${ }^{*}$, Amprin², dan Kahar ${ }^{3}$ \\ 1.2,3 Program Studi Teknik Pertanian, Sekolah Tinggi Pertanian Kutai Timur \\ JIn. Soekarno Hatta Sangatta, Kutai Timur, Kalimantan Timur, Kode Pos 75387 \\ ${ }^{1}$ Email: rusdi_m@stiperkutim.ac.id \\ *Penulis korespondensi: rusdi_m@stiperkutim.ac.id
}

\begin{abstract}
Most areas in Indonesia are experiencing a clean water (fresh water) crisis. Provision of clean water for all societies' levels is still a big problem, so it's necessary to process seawater into clean water by distillation system. Research was conducted on February 2021, at Land and Water Resources Engineering Laboratory, Agricultural Engineering Studies Program, East Kutai Agriculture College and Water Quality Laboratory, Mulawarman University. Research aimed was to determine the physical, chemical, and yield of seawater by temperature variations and distillation time using an electric heater. The distillation results obtained from field and laboratory tests consist of physical, chemical, and yield properties analysis. The water quality tested parameters is color, taste, odor, $\mathrm{pH}$, $C O D, D O$, sulfate and salinity. Based on the research, the physical water analysis (colorless, tasteless, Odorless) it was comply by the specified maximum limit standard. The chemical water analysis i.e. $\mathrm{pH}$, DO, salinity, sulfate it was comply by the maximum allowed standards $(\mathrm{pH} 6.511-6.894 \mathrm{mg} / \mathrm{L}$, DO 4.035$4.983 \mathrm{mg} / \mathrm{L}$, sulfate content $0.387-4.365 \mathrm{mg} / \mathrm{L}$, and salinity 0 (stable), except the COD incomply by the maximum allowable standard (COD 19.767-55.574mg/L.). Temperature variations and distillation time caused a differences in the volume value of distillation results. The higher the distillation temperature and time, then the resulting yield is getting bigger. The smallest yield founded at $100^{\circ} \mathrm{C}$ temperature and 30 minutes $\left(T_{1} W_{1}\right)$ as much as $31.5 \%$. The largest yield at temperature $200^{\circ} \mathrm{C}$, and 90 minutes $\left(T_{3} W_{3}\right)$ as much as $82.8 \%$.
\end{abstract}

Keywords: Chemical Properties, Distillation, Electric Heating, Physical Properties, Seawater, Yield

\begin{abstract}
ABSTRAK
Sebagian besar wilayah di Indonesia mengalami krisis air bersih (air tawar). Penyediaan air bersih bagi seluruh lapisan masyarakat masih merupakan satu masalah besar di Indonesia, sehingga perlu pengolahan air laut menjadi air bersih dengan sIstem destilasi. Penelitian ini dilaksanakan pada bulan Februari 2021, bertempat di Laboratorium Teknik Sumber Daya Lahan dan Air, Program Studi Teknik Pertanian, Sekolah Tinggi Pertanian Kutai Timur dan Laboratorium Kualitas Air Universitas Mulawarman. Penelitian bertujuan mengetahui sifat fisik, kimia, dan rendemen air laut dengan variasi temperatur dan waktu destilasi menggunakan pemenas elektrik. Hasil destilasi yang diperoleh dari pengujian lapangan dan uji laboratorium terdiri dari analisis sifat fisik, kimia, dan rendemen. Parameter kualitas air yang diuji dalam penelitian ini yaitu warna, rasa, bau, $\mathrm{pH}$, COD, DO, sulfat dan salinitas. Berdasarkan penelitian diketahui analisis air secara fisik (tidak berwarna, tidak berasa, tidak berbau) telah memenuhi standar batas maksimum yang ditentukan. Analisis air secara kimia $\mathrm{pH}$, DO, salinitas, sulfat telah memenuhi standar maksimum yang diperbolehkan $(\mathrm{pH}$ 6,511-6,894 $\mathrm{mg} / \mathrm{L}$, DO 4,035-4,983 mg/L. Kandungan sulfat 0,387-4,365 mg/, dan salinitas 0 (stabil), kecuali COD tidak memenuhi standar maksimum yang diperbolehkan (COD 19,767-55,574mg/L). Variasi temperatur dan waktu destilasi
\end{abstract}


menyebabkan perbedaan terhadap nilai volume hasil destilasi. Semakin tinggi temperatur dan waktu destilasi, maka rendemen yang dihasilkan semakin besar. Rendemen terkecil terdapat pada temperatur $100^{\circ} \mathrm{C}$, dan waktu 30 menit $\left(T_{1} W_{1}\right)$ sebesar $31,5 \%$. Sedangkan rendemen terbesar terdapat pada temperatur $200^{\circ} \mathrm{C}$, dan waktu 90 menit $\left(\mathrm{T}_{3} \mathrm{~W}_{3}\right)$ sebesar $82,8 \%$.

Kata kunci: Air Laut, Destilasi, Pemanas Elektrik, Rendemen, Sifat Fisik, Sifat Kimia

\section{Pendahuluan}

Indonesia adalah negara kepulauan dengan dua pertiga luas lautan, yaitu sekitar $3.288 .683 \mathrm{~km}$, dengan adanya garis pantai di hampir setiap pulau di Indonesia $( \pm 81.000$ $\mathrm{km}$ ) yang menjadikan Indonesia sebagai negara yang memiliki garis pantai terpanjang di dunia. Melihat Indonesia yang terletak di tengah kepungan air laut, namun kekurangan air bersih banyak menimpa masyarakat yang tinggal di pesisir pantai. Penyediaan air bersih bagi seluruh lapisan masyarakat masih merupakan satu masalah besar di Indonesia (lqbal et al., 2019). Sebagian besar wilayah dilndonesia mengalami krisis air tawar (air bersih), hal ini biasanya dialami sebagian besar masyarakat pesisir (Tambunan et al., 2015).

Pada Provinsi Kalimantan Timur khususnya di Kabupaten Kutai Timur, krisis air bersih terjadi akibat tecemarnya sumber air baku, dalam penyediaan air bersih dilakukan perusahaan daerah air minum (PDAM) Kota Sangatta Kabupaten Kutai Timur. Laju tingkat pertumbuhan penduduk yang cukup tinggi per tahun di Kabupaten Kutai Timur yang didukung oleh sektor pertambangan dan penggalian terutama pertambangan non migas, maka dampaknya adalah meningkatnya dan bertambahnya pembangunan perumahan, pusat bisnis, perkantoran, dan pengembangan wilayah baru khususnya di daerah perkotaan, kondisi tersebutakan berpengaruh terhadap peningkatan kebutuhan air bersih di Kota Sangatta (Astuti, 2014).

Lebih lanjut Astuti (2014) mengatakan, Kabupaten Kutai Timur, Kota Sangatta untuk mendapatkan air bersih sangat sulit, dikarenakan air telah dicemari oleh berbagai pencemaran baik yang berasal dari sumber domestik (rumah tangga, perkampungan, kota, pasar dan pembangunan jalan) ataupun sumber nondomestik (pabrik, industri dan tambang). Untuk itu perlu alternatif lain untuk mendapatkan air bersih dengan cara memanfaatkan air laut. Kabupaten Kutai Timur memiliki luas lautan 2.294,91 km² sehingga sumber air asin begitu melimpah, untuk mengubah air laut menjadi air tawar perlu dilakukan penyulingan (destilasi).

Proses destilasi air laut berlangsung dengan cara merebus air agar air tersebut berubah menjadi uap, yang mana akan terjadi perubahan wujud menjadi air tawar. Salah satu cara agar merubah air laut menjadi air tawar adalah proses perebusan air. Proses merebus air laut tersebut direbus dalam tabung yang bernama tabung evaporator. Suhu pada tabung evaporator dipantau oleh pemanas elektrik (Taqwa et al., 2020). 
Teknologi penyulingan air atau destilasi untuk mendapatkan air tawar dari air laut telah lama dikenal. Konsepnya sederhana, yaitu dengan menguapkan air laut dengan cara dipanaskan, yang kemudian uap air tersebut diembunkan dan dikumpulkan ke dalam suatu wadah penampung sehingga didapatkan air tawar. Pengolahan air laut untuk di jadikan air bersih (air tawar) dengan proses destilasi dapat dijadikan solusi untuk mengatasi permasalahan akses air bersih. Proses pembuatan alat yang sangat mudah, biayanya terjangkau dan bisa di gunakan oleh semua kalangan. Guna menunjang pemenuhan kebutuhan air bersih, maka perlu pengembangan alat destilasi untuk mendapatkan air bersih secara optimal (kuantitas maupun kualitas air) (Jasman \& Jusran, 2019). Tujuan dari penelitian ini sebagai berikut mengetahui kualitas air hasil destilasi air laut menggunakan pemanas elektrik meliputi syarat fisik, syarat kimia, dan rendemen.

\section{Metodologi Penelitian}

\section{Waktu dan Tempat}

Penelitian ini dilaksanakan pada bulan Februari 2021, bertempat di Laboratorium Teknik Sumber Daya Lahan dan Air (TSLA), Program Studi Teknik Pertanian, Sekolah Tinggi Pertanian (STIPER) Kutai Timur dan Laboratorium Kualitas Air Universitas Mulawarman (UNMUL) untuk pengujian kualitas air. Pengambilan sampel pada penelitian ini dilakukan di Pantai Kenyamukan lebih tepatnya di Pelabuhan Kudungga (Kenyamukan Sangatta Kutai Timur). Pengambilan sampel diambil di sepanjang jembatan pelabuhan dengan panjang $1.200 \mathrm{~m}$. Pada tepi ujung jembatan 0 meter (sampel I) sebanyak 10.000 $\mathrm{ml}$, di pertengahan jembatan 600 meter (sampel II) sebanyak $10.000 \mathrm{ml}$, dan diujung jembatan 1.200 meter (sampel III) sebanyak 10.000 ml. Masing-masing sampel didestilasi dengan temperatur dan waktu yang berbeda, dan untuk setiap destilasi menggunakan air laut sebanyak $1.000 \mathrm{ml}$. Peta lokasi pelabuhan dan pengambilan sampel seperti pada gambar 1 dan 2 dibawah ini.

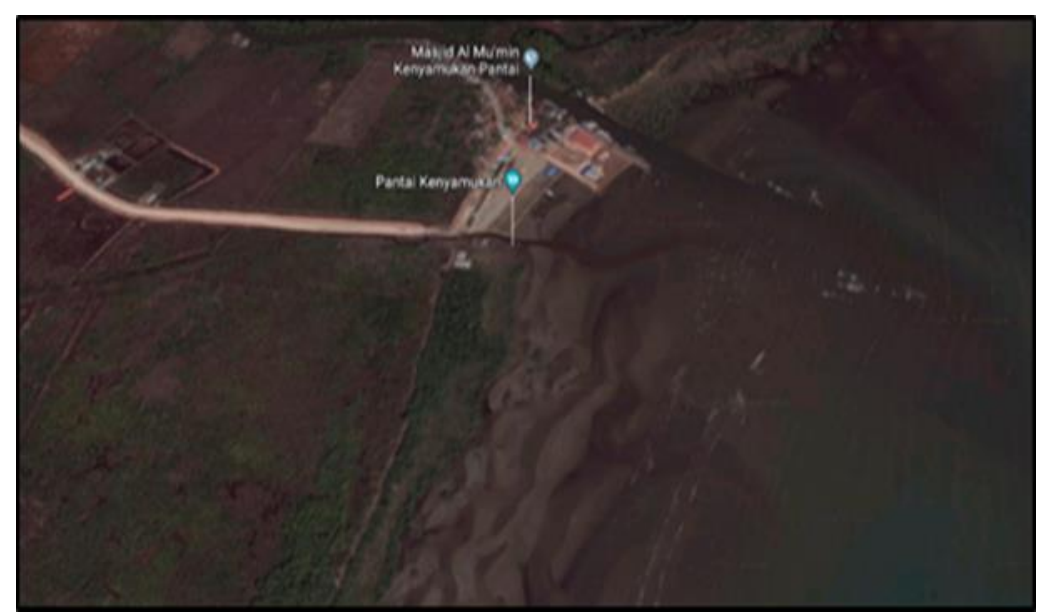

Gambar 1. Lokasi Pelabuhan Kudungga (Kenyamukan) 


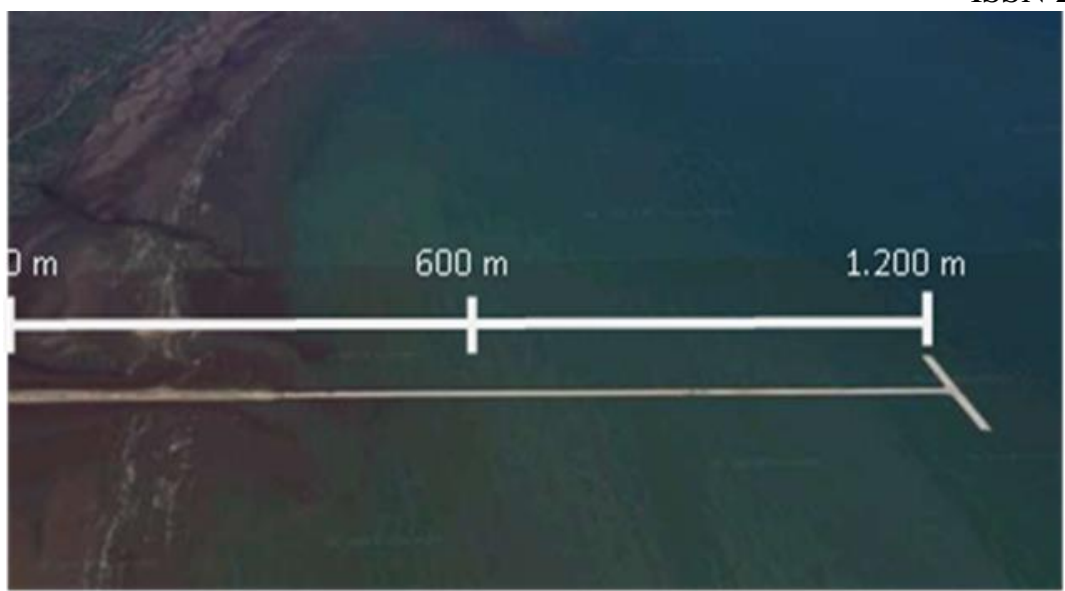

Gambar 2. Lokasi pengambilan sampel

Proses destilasi air laut dilaksanakan di Laboratorium Teknik Sumber Daya Lahan dan Air (TSLA), Program Studi Teknik Pertanian, Sekolah Tinggi Pertanian (STIPER) Kutai Timur, dengan menguji langsung sifat fisik dan rendemen air yang dihasilkan. Proses analisis sifat kimia air dilaksanakan di Laboratorium Kualitas Air Universitas Mulawarman (UNMUL), dengan menguji semua sampel air yang dihasilkan dari variasi temperatur dan waktu destilasi.

\section{Alat dan Bahan}

Alat yang digunakan dalam penelitian ini yaitu alat destilasi, pemanas elektrik, botol/wadah penampung hasil dari destilasi air laut, stopwatch, dan gelas ukur. Bahan yang digunakan dalam penelitian ini yaitu air laut untuk didestilasi.

\section{Metode Penelitian}

Pengujian air laut hasil destilasi terdiri dari analisis sifat fisika, kimiawi, dan rendemen. Sifat fisika yang diamati adalah bau, rasa dan warna, diuji langsung dengan metode organoleptik yaitu dilakukan oleh 20 orang responden untuk mencium bau, mencicipi rasa dan melihat warna sampel air hasil destilasi air laut menggunakan pemanas elektrik, kemudian dianalisis berdasarkan hasil pendapat responden mengenai bau (berbau atau tidak), rasa (berasa atau tidak) dan warna (berwarna atau tidak).

Sifat kimiawi diuji langsung di Laboratorium Kualitas Air, Universitas Mulawarman (UNMUL). Hal yang diamati meliputi derajat keasaman $(\mathrm{pH})$, Chemical Oxygen Demand (COD), Dissolved Oxygen (DO), sulfat dan salinitas, kemudian hasilnya dianalisis berdasarkan nilai hasil laboratorium. Salah satu tujuan dari destilasi air laut adalah untuk mengetahui rendemen dari masing-masing sampel yang diuji. Rendemen diukur berdasarkan perbandingan volume hasil dibagi volume awal dikali 100\%. 


\section{Prosedur Penelitian}

Penelitian dilaksanakan menggunakan seperangkat alat alat destilasi sederhana. Bahan Baku air laut sebanyak $10.000 \mathrm{ml}$ untuk sampel 1, $10.000 \mathrm{ml}$ untuk sampel II, dan $10.000 \mathrm{ml}$ untuk sampel III. Untuk setiap perlakuan pada proses destilasi volume sampel yang digunakan adalah $1.000 \mathrm{ml}$, sampel dimasukan ke dalam tungku pemasak, dididihkan dengan pemanas elektrik dengan perlakuan kontrol temperatur pada pemenas elektrik dan waktu destilasi yang berbeda, dapat dilihat pada tabel 1 dibawah ini:

Tabel 1. Variasi temperatur dan waktu destilasi

\begin{tabular}{cccc}
\hline \multirow{2}{*}{ Temperatur } & \multicolumn{3}{c}{ Waktu Destilasi } \\
\cline { 2 - 4 } & $\mathbf{W}_{\mathbf{1}}$ & $\mathbf{W}_{\mathbf{2}}$ & $\mathbf{W}_{\mathbf{3}}$ \\
\hline $\mathrm{T}_{1}$ & $\mathrm{~T}_{1} \mathrm{~W}_{1}$ & $\mathrm{~T}_{1} \mathrm{~W}_{2}$ & $\mathrm{~T}_{1} \mathrm{~W}_{3}$ \\
$\mathrm{~T}_{2}$ & $\mathrm{~T}_{2} \mathrm{~W}_{1}$ & $\mathrm{~T}_{2} \mathrm{~W}_{2}$ & $\mathrm{~T}_{2} \mathrm{~W}_{3}$ \\
$\mathrm{~T}_{3}$ & $\mathrm{~T}_{3} \mathrm{~W}_{1}$ & $\mathrm{~T}_{3} \mathrm{~W}_{2}$ & $\mathrm{~T}_{3} \mathrm{~W}_{3}$ \\
\hline
\end{tabular}

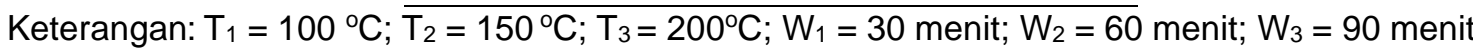

Hasil destilasi air laut untuk masing-masing sampel, dimana setiap sampel sebanyak Sembilan perlakuan, sehingga berjumlah 27 perlakuan kemudian dianalisis sifak fisiknya berdasarkan hasil uji organolektip, dianalisis sifat kimianya berdasarkan hasil yang didapatkan pada uji laboratorium, dan dianalisis rendemen berdasarkan volume yang dihasilkan.

\section{Hasil dan Pembahasan}

\section{Analisis Sifat Fisik (Bau, Rasa, dan Warna) Air Laut Hasil Destilasi}

Salah satu tujuan dari destilasi air laut adalah untuk mengetahui sifat fisik dari air hasil destilasi untuk masing-masing sampel yang diuji menggunakanmetode organoleptik dengan bantuan 20 orang responden. Sifat fisik yang dianalisis pada penelitian ini terdiri dari bau, rasa, dan warna. dapat dilihat pada tabel 2 dibawah ini.

Tabel 2. Analisis organolektip sifat fisik hasil destilasi

\begin{tabular}{clcccc}
\hline No & Parameter & \multicolumn{1}{c}{ Alat } & Hasil & Analisis & $\begin{array}{c}\text { Responden } \\
\text { (orang) }\end{array}$ \\
\hline 1 & Warna & Indra pengelihatan (mata) & Tidak berwarna & Memenuhi syarat & 20 \\
2 & Rasa & Indra perasa (lidah) & Tidak berasa & Memenuhi syarat & 20 \\
3 & Bau & Indra pencium (hidung) & Tidak berbau & Memenuhi syarat & 20 \\
\hline
\end{tabular}

Hasil yang diperoleh dari pengujian parameter bau, rasa, dan warna pada sampel air laut dengan variasi temperatur dan waktu destilasi menggunakan pemanas elektrik, menunjukkan tidak ada bau, tidak ada rasa, dan tidak ada warna pada sampel air hasil destilasi tersebut. Menurut Nicolay (2006), pengukuran bau, rasa, dan warna dilakukan dengan metode analisis organoleptik dengan mencium, mencicipi, dan melihat air hasil destilasi secara langsung pada setiap sampel, dimana bau, rasa, dan warna sebagai batas penilaian. Sementara itu, untuk mendapatkan data yang valid pengukuran dilakukan oleh minimal 3 observer. 
Berdasarkan hasil penelitian pada tabel 2 diatas, menunjukkan bahwa air hasil destilasi untuk semua sampel yang diuji dengan temperatur dan waktu yang berbeda, telah memenuhi syarat air bersih (air tawar) dan standar baku mutu (kadar maksimum). Menurut Peraturan Menteri Kesehatan Nomor 32/Menkes/Per/IX/2017, tentang standar baku mutu air bersih (air tawar), tentang parameter fisik air yaitu tidak berwarna, tidak berbau, dan tidak berasa. Hal ini sesuai pendapat Noya (2014) bahwa air bersih adalah air jernih tidak berwarna, tidak berasa, dan tidak berbau yang secara kimiawi mengandung hidrogen dan oksigen. Pendapat ini didukung oleh Taqwa et al., (2020) bahwa syarat fisika standar air bersih yaitu air jernih alias tidak keruh, tidak berwarna, tidak memiliki rasa asin (rasa tawar), dan tidak berbau.

\section{Nilai Sifat Kimia (pH, COD, DO, Sulfat, dan Salinitas) Air Laut Hasil Destilasi}

1. Nilai Derajat Keasaman $(\mathrm{pH})$

Derajat keasaman $(\mathrm{pH})$ perairan dapat diukur menggunakan $\mathrm{pH}$ meter yang berkisar antara 0-14. Hasil derajat keasaman $(\mathrm{pH})$ air laut setelah didestilasi untuk variasi temperatur dan waktu dapat dilihat pada tabel 3.

Tabel 3. Derajat Keasaman (pH) air hasil destilasi (sampel I, II, dan III)

\begin{tabular}{ccccc}
\hline \multirow{2}{*}{ Sampel } & \multirow{2}{*}{ Suhu } & \multicolumn{3}{c}{ Derajat Keasaman $(\mathbf{p H})$} \\
\cline { 3 - 5 } & & $\mathbf{W 1}$ & $\mathbf{W} 2$ & $\mathbf{W 3}$ \\
\hline \multirow{3}{*}{ I } & T1 & 6,511 & 6,512 & 6,512 \\
& T2 & 6,522 & 6,522 & 6,523 \\
& T3 & 6,541 & 6,542 & 6,543 \\
\hline \multirow{3}{*}{ II } & T1 & 6,653 & 6,653 & 6,654 \\
& T2 & 6,674 & 6,674 & 6,675 \\
& T3 & 6,681 & 6,682 & 6,683 \\
\hline \multirow{2}{*}{ III } & T1 & 6,867 & 6,868 & 6,869 \\
& T2 & 6,872 & 6,872 & 6,873 \\
& T3 & 6,894 & 6,895 & 6,897 \\
\hline
\end{tabular}

Berdasarkan tabel 3 diatas, dapat dilihat bahwa $\mathrm{pH}$ terkecil terdapat pada temperatur 1 (temperatur $100^{\circ} \mathrm{C}$ ) untuk ketiga sampel, baik sampel I, sampel II, maupun sampel III. Sedangkan $\mathrm{pH}$ terbesar terdapat pada temperatur III (temperatur $200^{\circ} \mathrm{C}$ ), untuk ketiga sampel, baik sampel I, sampel II, maupun sampel III. Nilai pH air hasil destilasi untuk ketiga sampel yang duji dengan temperatur dan waktu yang berbeda, dengan nilai antara 6,511 sampai 6,897. Berdasarkan hasil penelitian dan analisis uji laboratorium, menunjukkan bahwa terjadi penurunan nilai pH air hasil destilasi air laut dengan temperatur dan waktu destilasi yang berbeda, untuk semua sampel yang diuji. Walaupun perubahan nilai pH tidak terlalu jauh perbedaan bahkan cenderung meningkat dari sampel I sampai III, tetapi nilai pH masih mendekati nilai normal dan memenuhi syarat kualitas air bersih.

Menurut Jasman \& Jusran (2019) bahwa perairan laut maupun pesisir secara umum memiliki $\mathrm{pH}$ relatif lebih stabil dan berada pada kisaran antara 7,6-8,3. Nilai pH air dipengaruhi oleh beberapa faktor diantaranya adalah banyaknya limbah rumah tangga, 
limbah industri kimia, dan bahan bakar fosil ke dalam suatu perairan, sedangkan menurut menurut Standarisasi Nasional Indonesia (SNI) 06.6989.11-2004, tentang syarat standar maksimum $\mathrm{pH}$ air yang diperbolehkan adalah 6,5-8,5.

Derajat keasaman $(\mathrm{pH})$ menunjukkan tingkat keasaman atau basa pada air yang ditunjukkan dengan skala 0 sampai dengan 14. Untuk pH air bersih (air tawar) yang sesuai standar kesehatan adalah 6,5 s/d 8,5, pH juga akan menyebabkan perubahan kimiawi di dalam air. Tinggi atau rendahnya $\mathrm{PH}$ air dipengaruhi oleh senyawa/kandungan dalam air tersebut (Musli \& Fretes, 2016).

Daroni \& Arisandi (2020) menyatakan bahwa pH mempengaruhi konsentrasi logam berat di perairan. Kondisi pH lebih kecil dari 6,50 atau lebih besar dari 8,5 menyebabkan korosifitas pada pipa-pipa air dan dapat mengakibatkan beberapa senyawa kimia berubah menjadi racun yang dapat mengganggu kesehatan. Menurut Khotimah et al., (2017) bahwa $\mathrm{pH}$ air murni memiliki nilai 7, $\mathrm{pH}$ mencapai nilai $<7$ (perairan asam). Sebaliknya, nilai $\mathrm{pH}>7$ (perairan basa). Hal ini sesuai dengan pendapat Noya (2014) bahwa pH didefinisikan sebagai negatif logaritma konsentrasi molar ion $\mathrm{H}^{+}$dan sebagai negatif konsentrasi molar ion $\mathrm{OH}^{-}$. Air laut mempunyai $\mathrm{pH}$ antara 7,6-8,3 (Basa), Air tawar merupakan air yang tidak berasa dengan $\mathrm{pH}$ 7. Daroni \& Arisandi (2020) menyatakan nilai pH merupakan indikator baik buruknya suatu perairan. Kehidupan organisme yang hidup dalam suatu lingkungan perairan sangat berpengaruh terhadap konsentrasi ion $\mathrm{H}$ (hidrogen) atau $\mathrm{pH}$ dalam perairan.

2. Nilai Chemical Oxygen Demand (COD)

Hasil Chemical Oxygen Demand (COD) air laut setelah didestilasi untuk variasi temperatur dan waktu dapat dilihat pada tabel 4.

Tabel 4. Chemical Oxygen Demand (COD) air hasil destilasi (sampel I, II, dan III)

\begin{tabular}{ccccc}
\hline \multirow{2}{*}{ Sampel } & \multirow{2}{*}{ Suhu } & \multicolumn{3}{c}{ COD $\mathbf{( m g} / \mathbf{L})$} \\
\cline { 2 - 5 } & & W1 & W2 & W3 \\
\hline \multirow{2}{*}{ I } & T1 & 55,573 & 55,573 & 55,574 \\
& T2 & 29,163 & 29,164 & 29,164 \\
& T3 & 23,028 & 23,028 & 23,029 \\
\hline \multirow{2}{*}{ II } & T1 & 53,179 & 53,180 & 53,180 \\
& T2 & 28,794 & 28,795 & 28,795 \\
& T3 & 21,869 & 21,870 & 21,871 \\
\hline \multirow{2}{*}{ III } & T1 & 50,685 & 50,686 & 50,687 \\
& T2 & 26,956 & 26,957 & 26,958 \\
& T3 & 19,767 & 19,767 & 19,768 \\
\hline
\end{tabular}

Berdasarkan tabel 4, dapat dilihat bahwa nilai COD terkecil terdapat pada temperatur III (temperatur $200^{\circ} \mathrm{C}$ ), untuk ketiga sampel, baik sampel I, sampel II, maupun sampel III. Sedangkan nilai COD terbesar terdapat pada temperatur I (temperatur $100^{\circ} \mathrm{C}$ ), untuk ketiga sampel, baik sampel I, sampel II, maupun sampel III. Berdasarkan hasil pengujian laboratorium tabel 4 diatas, menunjukkan bahwa nilai COD air laut hasil destilasi untuk ketiga sampel yang duji dengan temperatur dan waktu yang berbeda, tidak memenuhi 
syarat, dengan nilai antara 19,767 sampai 55,574 mg/L. Berdasarkan SNI 06.6989.73.2009 batas maksimum yang diperbolehkan yaitu $10 \mathrm{mg} / \mathrm{L}$. Berdasarkan nilai COD yang didapatkan menunjukkan bahwa air hasil destilasi tidak memenuhi syarat dan menunjukkan bahwa air tersebut telah tercemar, hal ini tentu saja membahayakan bagi kesehatan.

Menurut Atima (2015), COD menggambarkan jumlah total bahan organik yang ada. COD adalah jumlah oksigen yang diperlukan untuk mengurai seluruh bahan organik yang terkandung dalam air, bila nilai COD telah cukup tinggi dan melebihi Baku mutu, maka sudah dapat diduga ada indikasi pencemaran bahan organik. Menurut Yulis et al., (2018) bahwa tingkat pencemaran suatu perairan dapat dianalisis juga berdasarkan Kadar COD (Chemical Oxygen Demand). Chemical Oxygen Demand (COD) atau kebutuhan oksigen kimia (KOK) merupakan jumlah oksigen yang dibutuhkan untuk mengoksidasi zat- zat organik yang ada dalam sampel air atau banyaknya oksigen yang dibutuhkan untuk mengoksidasi zat- zat organik menjadi $\mathrm{CO}_{2}$ dan $\mathrm{H}_{2} \mathrm{O}$. Berdasarkan baku mutu air konsentrasi $\mathrm{COD}<5 \mathrm{mg} / \mathrm{L}$ (pencemaran sangat ringan), COD 6-9 mg/L (pencemaran ringan), $C O D$ 10-15 mg/L (pencemaran sedang), dan jika COD $>16 \mathrm{mg} / \mathrm{L}$ disebut pencemaran berat.

\section{Nilai Dissolved Oxygen (DO)}

Hasil Dissolved Oxygen (DO) air laut setelah didestilasi untuk variasi temperatur dan waktu dapat dilihat pada tabel 5.

Tabel 5. Dissolved Oxygen (DO) air hasil destilasi (sampel I, II, dan III)

\begin{tabular}{ccccc}
\hline \multirow{2}{*}{ Sampel } & \multirow{2}{*}{ Suhu } & \multicolumn{3}{c}{ DO $\mathbf{~ m g / L ( p p m ) ~}$} \\
\cline { 3 - 5 } & & W1 & W2 & W3 \\
\hline \multirow{3}{*}{ I } & T1 & 4,226 & 4,227 & 4,227 \\
& T2 & 4,441 & 4,442 & 4,443 \\
& T3 & 4,982 & 4,983 & 4,983 \\
\hline \multirow{3}{*}{ II } & T1 & 4,174 & 4,175 & 4,175 \\
& T2 & 4,253 & 4,254 & 4,255 \\
& T3 & 4,767 & 4,767 & 4,768 \\
\hline \multirow{2}{*}{ III } & T1 & 4,035 & 4,036 & 4,037 \\
& T2 & 4,116 & 4,117 & 4,118 \\
& T3 & 4,544 & 4,545 & 4,546 \\
\hline
\end{tabular}

Berdasarkan tabel 5 diatas, dapat dilihat bahwa nilai DO terkecil terdapat pada temperatur 1 (temperatur $100^{\circ} \mathrm{C}$ ), untuk ketiga sampel, baik sampel I, sampel II, maupun sampel III. Sedangkan nilai DO terbesar terdapat pada temperatur III (temperatur $200^{\circ} \mathrm{C}$ ), untuk ketiga sampel, baik sampel I, sampel II, maupun sampel III. Berdasarkan hasil pengujian laboratorium tabel 5 diatas, menunjukkan bahwa nilai DO air laut hasil destilasi untuk ketiga sampel yang duji dengan temperatur dan waktu yang berbeda, telah memenuhi syarat, dengan nilai antara 4,035 sampai 4,983 mg/L. Berdasarkan SNI 06.6989.14.2004 batas maksimum yang diperbolehkan yaitu $6 \mathrm{mg} / \mathrm{L}$. Menurut Yulis et al., (2018) bahwa nilai tersebut masih memenuhi angka baku mutu yang ditetapkan, dimana 
berdasarkan PP No.82 Tahun 2001, batas nilai minimum DO adalah 3 ppm dan angka DO $>5$ ppm. Tinggi rendahnya kadar oksigen dipengaruhi oleh kekeruhan, aktivitas mikro organisme. Hal ini sesuai pernyataan Patty (2013), rendahnya kardar oksigen erat kaitannya dengan kekeruhan air laut dan juga diduga disebabkan semakin bertambahnya aktivitas mikro-organisme untuk menguraikan zat organik menjadi zat anorganik yang menggunakan oksigen terlarut (bioproses). Sedangkan tingginya kadar oksigen terlarut dikarenakan airnya jernih sehingga dengan lancarnya oksigen yang masuk kedalam air tanpa hambatan melalui proses difusi dan proses fotosintesis. Semakin tinggi jumlah DO maka kualitas air semakin baik, tetapi tidak melebihi batas maksimum yang ditentukan. Sumber utama oksigen terlarut dalam air adalah difusi dari udara dan hasil fotosintesis organisme yang mempunyai klorofil yang hidup di perairan (Megawati et al., 2014).

Menurut Khotimah et al., (2017), keadaan oksigen dalam air sangat dipengaruhi oleh beberapa faktor antara lain adalah suhu. Kelarutan oksigen ke dalam air terutama dipengaruhi oleh faktor suhu. Kelarutan gas oksigen pada suhu tinggi relatif lebih tinggi. Kelarutan oksigen pada air laut relatif lebih rendah 1-5 ppm dari angka tersebut di atas karena pengaruh salinitas (kadar garam). Menurut Daroni \& Arisandi (2020) bahwa kandungan oksigen terlarut dipengaruhi oleh nilai kecerahan yang terdapat di perairan, nilai kecerahan yang tinggi sangat berpengaruh terhadap bertambahnya Kadar oksigen terlarut.

\section{Nilai Kandungan Sulfat}

Menurut Wulan (2005) bahwa kandungan sulfat yang berlebihan dalam air dapat mengakibatkan bau dan korosi pada pipa. Semakin rendah kandungan sulfat di dalam air maka semakin aman air tersebut untuk dikonsumsi. Hasil sulfat $(\mathrm{mg} / \mathrm{L})$ air laut setelah didestilasi untuk variasi temperatur dan waktu dapat dilihat pada tabel 6 dibawah ini.

Tabel 6. Hasil pengujian sulfat (mg/L) air hasil destilasi (sampel I, II, dan III)

\begin{tabular}{ccccc}
\hline \multirow{2}{*}{ Sampel } & \multirow{2}{*}{ Suhu } & \multicolumn{3}{c}{ Sulfat (mg/L) } \\
\cline { 2 - 5 } & & W1 & W2 & W3 \\
\hline \multirow{3}{*}{ I } & T1 & 4,364 & 4,365 & 4,365 \\
& T2 & 2,005 & 2,005 & 2,006 \\
& T3 & 1,242 & 1,243 & 1,244 \\
\hline \multirow{2}{*}{ II } & T1 & 4,169 & 4,170 & 4,171 \\
& T2 & 1,984 & 1,985 & 1,986 \\
& T3 & 1,020 & 1,021 & 1,022 \\
\hline \multirow{2}{*}{ III } & T1 & 3,984 & 3,985 & 3,986 \\
& T2 & 1,644 & 1,645 & 1,646 \\
& T3 & 0,387 & 0,388 & 0,389 \\
\hline
\end{tabular}

Berdasarkan tabel 6 diatas, dapat dilihat bahwa kandungan sulfat terkecil terdapat pada temperatur III (temperatur $200^{\circ} \mathrm{C}$ ), untuk ketiga sampel, baik sampel I, sampel II, maupun sampel III. Sedangkan kandungan sulfat terbesar terdapat pada temperatur 1 (temperatur $100^{\circ} \mathrm{C}$ ), untuk ketiga sampel, baik sampel I, sampel II, maupun sampel III. Berdasarkan hasil pengujian laboratorium tabel 6 diatas, menunjukkan bahwa kandungan 
sulfat air laut hasil destilasi untuk ketiga sampel yang duji dengan temperatur dan waktu yang berbeda, telah memenuhi syarat, dengan nilai rata-rata 0,387 sampai 4,365 mg/L. Standar maksimum kandungan sulfat di dalam air yang diperbolehkan menurut SNI 6989.20.2009 adalah $250 \mathrm{mg} / \mathrm{L}$. Menurut Nababan (2018), ion sulfat adalah salah satu anion yang banyak terjadi pada air alam, dan sangat penting dalam penyediaan air untuk umum karena pengaruh pencucian perut yang terjadi pada manusia apabila ada dalam konsentrasi yang cukup besar. Batas maksimum di konsumsi manusia adalah $250 \mathrm{mg} / \mathrm{L}$ dalam air. Kandungan konsentrasi yang tinggi dalam air minum dapat menyebabkan diare. Diare dapat menyebabkan dehidrasi, terutama pada bayi dan anak kecil yang sudah mengidap mikroba diare dalam tubuh. Efek laxative yang ditimbulkan berupa rasa mual dan ingin muntah. Standar maksimal yang ditetapkan oleh Peraturan Menteri Kesehatan Repbulik Indonesia No. 492/MENKES/PER/IV/2010 untuk sulfat dalam air minum adalah sebesar $250 \mathrm{mg} / \mathrm{L}$.

Hasil destilasi untuk ketiga sampel yang duji dengan temperatur dan waktu yang berbeda, telah memenuhi syarat, dengan nilai rata-rata 0,387 sampai $4,365 \mathrm{mg} / \mathrm{L}$, memenuhi standar Peraturan Menteri Kesehatan Republik Indonesia No. 492/MENKES/PER/IV/2010, dimana kadar sulfat yang diizinkan maksimal sebesar 250 $\mathrm{mg} / \mathrm{L}$, dan dapat dinyatakan bahwa air tersebut aman untuk dikonsumsi. Menurut Wulan (2005), kandungan sulfat yang berlebihan dalam air dapat mengakibatkan kerak air yang keras pada alat merebus air (panci) selain itu juga mengakibatkan bau dan korosi pada pipa. Hal ini tentu saja sangat berpengaruh terhadap kesehatan seperti terkena diare dan menimbulkan rasa mual. Semakin rendah kandungan sulfat di dalam air maka semakin aman air tersebut untuk dikonsumsi.

\section{Nilai Salinitas}

Pengujian salinitas terhadap air hasil destilasi ini sangat penting karena kandungan garam mempengaruhi terhadap kualitas air tawar (air bersih). Hasil Salinitas air laut setelah didestilasi untuk variasi temperatur dan waktu dapat dilihat pada tabel 7.

Tabel 7. Hasil pengujian salinitas (\%o) air hasil destilasi (sampel I, II, dan III)

\begin{tabular}{ccccc}
\hline \multirow{2}{*}{ Sampel } & \multirow{2}{*}{ Suhu } & \multicolumn{3}{c}{ Salinitas (\%o) } \\
\cline { 2 - 5 } & & W1 & W2 & W3 \\
\hline \multirow{3}{*}{ I } & T1 & 0 & 0 & 0 \\
& T2 & 0 & 0 & 0 \\
& T3 & 0 & 0 & 0 \\
\hline \multirow{3}{*}{ II } & T1 & 0 & 0 & 0 \\
& T2 & 0 & 0 & 0 \\
& T3 & 0 & 0 & 0 \\
\hline \multirow{3}{*}{ III } & T1 & 0 & 0 & 0 \\
& T2 & 0 & 0 & 0 \\
& T3 & 0 & 0 & 0 \\
\hline
\end{tabular}


Berdasarkan tabel 7 diatas, dapat dilihat bahwa kandungan salinitas air laut hasil destilasi untuk ketiga sampel yang duji dengan temperatur dan waktu destilasi yang berbeda adalah nol (stabil). Berdasarkan penelitian dan hasil pengujian laboratorium diatas, menunjukkan bahwa kandungan salinitas air hasil destilasi untuk ketiga sampel yang diuji dengan temperatur dan waktu destilasi yang berbeda mengalami penurunan sampai ke tingkat stabil (nilai 0). Hasil pengujian terhadap hasil destilasi ini menunjukkan bahwa air tergolong tawar karena memiliki salinitas kurang dari 0,5\%. Kadar salinitas yang tinggi tentu saja berpengaruh terhadap kesehatan. Sebaliknya semakin rendah nilai salinitas, maka air tersebut dalam kondisi semakin aman dan telah memenuhi syarat, dengan nilai rata-rata 0\%o (stabil). Menurut Amri et al., (2018), alinitas adalah kandungan garam dalam suatu perairan dan besarannya dinyatakan dalam permil. Menurut Nova \& Misbah (2012) untuk ukuran perairan di dunia, memiliki kadar garam sekitar 3-4\%.

Menurut Khotimah et al (2017) bahwa salinitas dapat didefinisikan sebagai jumlah total dalam gram bahan-bahan terlarut dalam satu kilogram air. Dalam keadaan stabil di laut nilai salinitasnya berkisar antara 34\%o sampai 35\%o. Menurut Daroni \& Arisandi (2020) bahwa salinitas adalah konsentrasi kandungan garam terlarut yang dihasilkan dari satu kilogram air laut. Salinitas termasuk parameter yang cukup penting dan merupakan faktor pembatas bagi organisme di perairan. Hal ini sesuai pernyataan Hamuna et al., (2018) bahwa salinitas merupakan konsentrasi seluruh larutan garam yang diperoleh dalam air laut, dimana salinitas air berpengaruh terhadap tekanan osmotik air, semakin tinggi salinitas maka semakin besar pula tekanan osmotiknya. Perbedaan salinitas perairan dapat terjadi karena adanya perbedaan penguapan dan presipitasi.

\section{Nilai Rendemen Air Laut Hasil Destilasi}

Rendemen diukur berdasarkan perbandingan volume hasil dibagi volume awal dikali $100 \%$. Hasil rendemen air laut setelah didestilasi untuk variasi temperatur dan waktu dapat dilihat pada tabel 8 dibawah ini.

Tabel 8. Rendemen air hasil destilasi (sampel I, II, dan III)

\begin{tabular}{ccccc}
\hline \multirow{2}{*}{ Sampel } & \multirow{2}{*}{ Suhu } & \multicolumn{3}{c}{ Rendemen (\%) } \\
\cline { 2 - 5 } & & W1 & W2 & W3 \\
\hline \multirow{2}{*}{ I } & T1 & 31,5 & 32 & 33,5 \\
& T2 & 59,5 & 60,5 & 61,5 \\
& T3 & 80,4 & 81,7 & 82,5 \\
\hline \multirow{2}{*}{ II } & T1 & 31,7 & 32,2 & 33,6 \\
& T2 & 59,7 & 60,6 & 61,8 \\
& T3 & 80,5 & 81,8 & 82,7 \\
\hline \multirow{2}{*}{ III } & T1 & 31,8 & 32,4 & 33,8 \\
& T2 & 59,7 & 60,7 & 62,0 \\
& T3 & 80,7 & 81,9 & 82,8 \\
\hline
\end{tabular}


Berdasarkan tabel 8 diatas, dapat dilihat bahwa rendemen terkecil terdapat pada temperatur 1 (temperatur $100^{\circ} \mathrm{C}$ ), untuk ketiga sampel, baik sampel I, sampel II, maupun sampel III. Sedangkan rendemen terbesar terdapat pada temperatur 3 (temperatur $200^{\circ} \mathrm{C}$ ), untuk ketiga sampel, baik sampel I, sampel II, maupun sampel III. Kecilnya rendemen yang dihasilkan pada temperatur 1 (temperatur $100^{\circ} \mathrm{C}$ ), untuk ketiga sampel, baik sampel I, sampel II, maupun sampel III, dikarenakan volume hasil destilasi yang dihasilkan masih sedikit jika dibanding dengan temperatur 2 dan temperatur 3, variasi temperatur dan waktu destilasi mempunyai pengaruh yang besar terhadap volume hasil yang dihasilkan dari destilasi air laut, sehingga akan berpengaruh juga terhadap nilai rendemen yang dihasilkan.

Berdasarkan tabel 8 diatas, dapat dilihat bahwa rendemen terkecil terdapat pada temperatur $100^{\circ} \mathrm{C}$, dan waktu 30 menit $\left(T_{1} W_{1}\right)$ sebesar $31,5 \%$. Sedangkan rendemen terbesar terdapat pada temperature $200^{\circ} \mathrm{C}$, dan waktu 90 menit $\left(\mathrm{T}_{3} \mathrm{~W}_{3}\right)$ sebesar $82,8 \%$. Hal ini dapat diketahui bahwa, variasi temperatur dan waktu mempunyai pengaruh yang besar terhadap volume hasil yang dihasilkan, sehingga berpengaruh juga terhadap nilai rendemen yang dihasilkan. Semakin kecil temperatur dan waktu destilasi, maka semakin kecil juga volume destilasi yang dihasilkan, begitu juga sebaliknya semakin besar temperature dan waktu destilasi, maka semakin besar juga volume destilasi yang dihasilkan, dimana semakin kecil volume hasil yang dihasilkan pada saat destilasi, maka volume sisa destilasi akan semakin besar, dan rendemen hasil destilasi akan semakin kecil. Sedangkan semakin banyak volume hasil yang dihasilkan pada saat destilasi, maka volume sisa destilasi semakin kecil, dan rendemen hasil destilasi semakin besar.

\section{Kesimpulan}

Dari hasil penelitian ditarik kesimpulan bahwa analisis sifat fisik air (tidak berwarna, tidak berasa, tidak berbau) telah memenuhi syarat dan standar mutu (kadar maksimum) air bersih (air tawar), sesuai dengan Peraturan Menteri Kesehatan Nomor 32/Menkes/Per/IX/2017. Analisis sifat kimia pH, DO, salinitas, sulfat telah memenuhi standar maksimum yang diperbolehkan $(\mathrm{pH} \mathrm{6.511-6.894} \mathrm{mg/L,} \mathrm{DO} \mathrm{4.035-4.983} \mathrm{mg/L,}$ kandungan sulfat 0.387-4.365 mg/, dan Salinitas 0 (Stabil). Kecuali COD tidak memenuhi standar maksimum yang diperbolehkan (COD 19.767-55.574mg/L.), sesuai dengan Peraturan Menteri Kesehatan Nomor 492/Menkes/Per/IV/2010. Analisis rendemen air, variasi temperatur dan waktu destilasi menyebabkan perbedaan terhadap nilai volume hasil destilasi. Semakin tinggi temperatur dan waktu destilasi, maka rendemen yang dihasilkan semakin besar. Rendemen terkecil terdapat pada temperatur $100^{\circ} \mathrm{C}$, dan waktu 30 menit $\left(\mathrm{T}_{1} \mathrm{~W}_{1}\right)$ sebesar $31,5 \%$, sedangkan rendemen terbesar terdapat pada temperatur $200^{\circ} \mathrm{C}$, dan waktu 90 menit $\left(\mathrm{T}_{3} \mathrm{~W}_{3}\right)$ sebesar $82,8 \%$. 


\section{Daftar Pustaka}

Amri, K., Muchlizar, \& Ma'mun, A. (2018). Variasi Bulanan Salinitas, pH, Dan Oksigen Terlarut Di Perairan Estuari Bengkalis. Majalah IImiah Globë, 20(2), 57-66. https://doi.org/http://dx.doi.org/10.24895

Astuti, N. (2014). Penyediaan Air Bersih Oleh Perusahaan Daerah Air Minum (PDAM) Kota Sangatta Kabupaten Kutai Timur. EJournal Administrasi Negara, 3(2), 678-689.

Atima, W. (2015). Bod Dan Cod Sebagai Parameter Pencemaran Air dan Baku Mutu Air Limbah. Jurnal Biology Science \& Education, 4(1), 83-93. https://doi.org/10.33477/bs.v4i1.532

Daroni, T. A., \& Arisandi, A. (2020). Analisis BOD (Biological Oxygen Demand) Di Perairan Desa Prancak Kecamatan Sepulu, Bangkalan. Juvenil, 1(4), 558-566. https://doi.org/https://doi.org/10.21107/juvenil.v1i4.9037

Hamuna, B., Tanjung, R. H. R., Suwito, Maury, H. K., \& Alianto. (2018). Kajian Kualitas Air Laut dan Indeks Pencemaran Berdasarkan Parameter Fisika-Kimia di Perairan Distrik Depapre, Jayapura. Jurnal IImu Lingkungan, 16(1), 35-43. https://doi.org/10.14710/jil.16.1.35-43

lqbal, S., Sukmawaty, Putra, G. M. D., \& Setiawati, D. A. (2019). Analisis Kinerja Alat Desalinasi Air Laut Penghasil Air Tawar dan Garam dengan Menggunakan Tenaga Surya. Jurnal Agrotek Ummat, 6(1), 29. https://doi.org/10.31764/agrotek.v6i1.988

Jasman, \& Jusran, M. (2019). Modifikasi Alat Pengolahan Air Laut Menjadi Air Bersih. Jkl, 9(1), 1-9.

Khotimah, H., Anggraeni, E. W., \& Setianingsih, A. (2017). Karakterisasi Hasil Pengolahan Air Menggunakan Alat Destilasi. Jurnal Chemurgy, 1(2), 34-38. https://doi.org/10.30872/cmg.v1i2.1143

Megawati, C., Yusuf, M., \& Maslukah, L. (2014). Sebaran kualitas perairan ditinjau dari zat hara, oksigen terlarut dan $\mathrm{pH}$ di Perairan Selat Bali bagian selatan. Jurnal Oseanografi., 3(2), 142-150. Retrieved from ownload.portalgaruda.org/article.php?article $=156301 \& \mathrm{va}$

Musli, V., \& Fretes, R. de. (2016). Analisis Kesesuaian Parameter Kualitas Air Minum Dalam Kemasan Yang Dijual Di Kota Ambon Dengan Standar Nasional Indonesia (SNI). Arika, 10(1), 57-74.

Nababan, G. R. J. (2018). Penentuan Kadar Sulfat Dalam Air Sumur Bor Dan Air Filter Medan Permai Dengan Menggunakan Alat Spektrofotometer Portable DR-2010. Tugas akhir Fakultas Matematika dan IImu Pengetahuan Alam. Universitas Sumatera Utara, Medan.

Nicolay, X. (2006). Odors in the Food Industry. In K. Kristbergsson (Ed.), Odors in the Food Industry. https://doi.org/10.1007/978-0-387-34124-8

Nova, S. M. K., \& Misbah, M. N. (2012). Analisis Pengaruh Salinitas dan Suhu Air Laut Terhadap Laju Korosi Baja A36 pada Pengelasan SMAW. Jurnal Teknik Its, 1(1), 7577. https://doi.org/ISSN: 2301-9271

Noya, Y. (2014). Teknologi Tepat Guna Mengubah Air Laut Menjadi Air Tawar. Seminar Nasional Basic Science VI F-MIPA UNPATTI. Sains Membangun Karaketer Dan Berpikir Kritis Untuk Kesejahteraan Masyarakat, Ambon 07 Mei 2014, 1-12. Ambon: Fakultas Matematika dan IImu Pengetahuan Alam, Universitas Pattimura. 
Patty, S. I. (2013). Jurnal IImiah Platax DISTRIBUSI SUHU, SALINITAS DAN OKSIGEN TERLARUT DI PERAIRAN KEMA, SULAWESI UTARA 1 Distribution Temperature , Salinity And Dissolved Oxygen In Waters Kema , North Sulawesi Jurnal Ilmiah Platax. Ilmiah Platax, 1(3), 148-157.

Pemerintah Republik Indonesia (PP). (2001). Peraturan Pemerintah Nomor 82 Tahun 2001 Tentang Pengelolaan Kualitas Air Dan Pengendalian Pencemaran Air.

Permenkes RI. (2010). Peraturan Menteri Kesehatan Republik Indonesia Nomor 492/Menkes/Per/IV/2010 Tentang Persyaratan Kualitas Air Minum.

Permenkes RI. (2017). Peraturan Menteri Kesehatan Nomor 32/Menkes/Per/IX/2017 Tentang Standar Baku Mutu Kesehatan Lingkungan Dan Persyaratan Kesehatan Air Untuk Keperluan Higiene Sanitasi, Kolam Renang, Solus Per Aqua dan Pemandian Umum.

Standarisasi Nasional Indonesia (SNI). (2004). SNI 06-6989.11-2004 Tentang Air dan Air Limbah - Bagian 11: Cara Uji Derajat Keasaman $(\mathrm{pH})$ dengan Menggunakan Alat $\mathrm{pH}$ Meter. Jakarta: BSNI.

Standarisasi Nasional Indonesia (SNI). (2009). Standar Nasional Indonesia 6989.2:2009 Tentang Air dan Air Limbah - Bagian 2: Cara uji Kebutuhan Oksigen Kimiawi (Chemical Oxygen Demand/COD) dengan Refluks Tertutup secara Spektrofotometer. Jakarta: BSNI.

Tambunan, F. S., Edisar, M., \& Junandi, M. (2015). Destilasi Air Laut Menggunakan Pemanas Matahari Dengan Reflektor Cermin Cekung. JOM FMIPA, 2(1), 116-122.

Taqwa, B. B., Rosalina, R., \& Ramza, H. (2020). Perancangan Alat Proses Distilasi Air Laut Menggunakan Pemanas Elektrik. Prosiding Seminar Nasional Teknoka Ke 5 FT UHAMKA, Jakarta 28 November 2020, 5(2502), 204-214. https://doi.org/10.22236/teknoka.v5i.327

Wulan, A. I. S. (2005). Kualitas Air Bersih Untuk Pemenuhan Kebutuhan Rumah Tangga Di Desa Pesarean Kecamatan Adiwerna Kabupaten Tegal. Skripsi Fakultas IImu Sosial. Universitas Negeri Semarang, Semarang.

Yulis, P. R., Desti, \& Febliza, A. (2018). Analisis Kadar DO, BOD, dan COD Air Sungai Kuantan Terdampak Penambangan Emas Tanpa Izin. Jurnal Bioterdidik Wahana Eksperisi IImiah, 6(3), 1-11. 